\title{
Structures and DNA-Binding and Cleavage Properties of Ternary Copper(II) Complexes of Glycine with Phenanthroline, Bipyridine, and Bipyridylamine
}

\author{
Masahiro Yodoshi, Mamiko Odoko, and Nobuo OKaвE* \\ Faculty of Pharmaceutical Sciences, Kinki University; 3-4-1 Kowakae, Higashiosaka, Osaka 577-8502, Japan.
}

Received November 27, 2006; accepted February 22, 2007

The crystal structures of the series of three complexes, $[\mathrm{Cu}(\mathrm{Gly})(\mathrm{bpy}) \mathrm{Cl}] \cdot 2 \mathrm{H}_{2} \mathrm{O}(1)(\mathrm{Gly}=\mathrm{glycine}$; bpy $=$ 2,2'-bipyridine) ${ }^{1)}\left[\mathrm{Cu}(\mathrm{Gly})(\right.$ phen $) \mathrm{Cl}_{2} \cdot 7 \mathrm{H}_{2} \mathrm{O}$ (2) (phen=1,10-phenanthroline), and $\left[\mathrm{Cu}(\mathrm{Gly})(\mathrm{bpa})\left(\mathrm{H}_{2} \mathrm{O}\right) \mathrm{Cl}\right](3)$ (bpa $=2,2^{\prime}$-bipyridylamine) were determined, and the coordination modes of $\mathrm{Cu}$ (II) ternary complexes were compared. The central $\mathrm{Cu}$ (II) atoms of complexes 1 and 3 have a similar distorted octahedral coordination geometry, while the $\mathrm{Cu}$ (II) atom of complex 2 has a distorted square pyramidal coordination. In all complexes, the aromatic heterocyclic compounds bpy, phen, and bpa, behave as a bidentate $\mathrm{N}, \mathrm{N}^{\prime}$ ligand, and Gly behaves as a bidentate N,O ligand. DNA-binding properties of the complexes to calf thymus (CT) DNA were studied by using the fluorescence method. Each of the complexes showed binding propensity to CT DNA with the relative order $2>3 \geq 1$. DNA cleavage studies indicate that each of the complexes, especially 2 , can cleave plasmid supercoiled pBR322 DNA in the presence of $\mathrm{H}_{2} \mathrm{O}_{2}$ and ascorbic acid with cleavage efficiency in the order $2>3 \simeq 1$. The degradation of the conformation of CT DNA by the complexes was also reflected in the decrease in the intensities of the characteristic $C D$ bands with the relative order $2>3 \simeq 1$.

Key words $\mathrm{Cu}(\mathrm{II})$ ternary complex; $\mathrm{Cu}(\mathrm{II})$ complex coordination mode; X-ray crystal analysis; glycine; N,N'ligands; DNA cleavage

Recently, the interaction of $\mathrm{Cu}(\mathrm{II})$ complexes with nucleic acid has attracted attention due to the study of mutation of genes and therapeutic approaches, ${ }^{2-6}$ ) because DNA is thought to be the target of the chemotherapy in the treatment of tumors. ${ }^{7)}$ Some ternary complexes of $\mathrm{Cu}$ (II) of 1,10phenanthroline(phen) have antitumor activity. ${ }^{8)}$ Various novel $\mathrm{Cu}$ (II) complexes with different ligand species have been designed and synthesized, ${ }^{3,9)}$ and the interaction of complexes with DNA has been characterized. Several groups ${ }^{1,3,10-13)}$ showed that some $\mathrm{Cu}(\mathrm{II})$ complexes with phen bind to DNA noncovalently in the minor groove and the free hydroxyl radicals formed due to the reaction of reduced $\mathrm{Cu}$ (II) complex with $\mathrm{H}_{2} \mathrm{O}_{2}$ lead to strand scission of DNA. Chikira and coworkers $^{9}$ investigated the orientation of $\mathrm{Cu}(\mathrm{II})$ complexes of phen or the ternary $\mathrm{Cu}$ (II) complexes with amino acids on DNA using electron paramagnetic reasonance method and suggested that the complexes bind to DNA with several different binding modes, such as non intercalative binding in the minor groove of DNA and/or intercalative binding. In addition to studies characterizing the interaction of $\mathrm{Cu}(\mathrm{II}) \mathrm{com}$ plexes with DNA, there were a few studies on the crystal structures of ternary $\mathrm{Cu}$ (II) complexes of amino acids with heterocyclic ligands, such as glutamic acid and phen, 2,2'bipyridine(bpy), ${ }^{4,14)}$ aspartic acid and bpy, ${ }^{15)}$ serine and phen, ${ }^{16)}$ proline and phen, ${ }^{17)}$ or glycine and phen. ${ }^{18,19)}$

We aimed to synthesize and determine three ternary $\mathrm{Cu}(\mathrm{II})$ complexes containing an amino acid, glycine ligand, and different heterocyclic ligands, phen, bpy, and 2,2'-bipyridylamine (bpa) and evaluate the ability the complexes to cleave DNA. The following three complexes (Fig. 1) were prepared and the structures, DNA binding, and DNA cleavage were examined. The three complexes are designated as $[\mathrm{Cu}(\mathrm{Gly})(\mathrm{bpy}) \mathrm{Cl}] \cdot 2 \mathrm{H}_{2} \mathrm{O}(\mathbf{1}),\left[\mathrm{Cu}(\mathrm{Gly})(\right.$ phen $) \mathrm{Cl}_{2} \cdot 7 \mathrm{H}_{2} \mathrm{O}$ (2), and $\left[\mathrm{Cu}(\mathrm{bpa})(\mathrm{phen})\left(\mathrm{H}_{2} \mathrm{O}\right) \mathrm{Cl}\right](\mathbf{3})$. We had previously determined the structure of (1), ${ }^{1}$ and the structures of (2) and (3) were determined in this study. The structural features of (1) were calculated using the previous coordination data ${ }^{1)}$ and cited together with those of $(\mathbf{2})$ and $(\mathbf{3})$ for comparison.

\section{Experimental}

Materials Analytical-grade bpy, phen, and bpa, glycine (Gly), copper(II) chloride dihydrate, other reagents and Agarose-Precast Gel (1\%) were obtained from Wako Pure Chemicals, Industries Ltd. (Osaka, Japan). Calf thymus DNA (CT DNA) and supercoiled plasmid pBR322 DNA (SC DNA, lot no. K4301A) were obtained from Sigma (St. Louis, MO, U.S.A.)

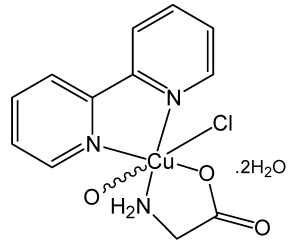

$[\mathrm{Cu}($ bpy $)(\mathrm{Gly}) \mathrm{Cl}] .2 \mathrm{H}_{2} \mathrm{O}(\mathbf{1})$

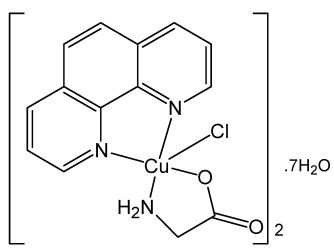

$\left[\mathrm{Cu}(\right.$ phen $)(\mathrm{Gly}) \mathrm{Cl}_{2} .7 \mathrm{H}_{2} \mathrm{O}(2)$

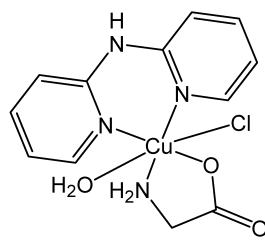

$\left[\mathrm{Cu}(\mathrm{bpa})(\mathrm{Gly})\left(\mathrm{H}_{2} \mathrm{O}\right) \mathrm{Cl}\right](3)$

Fig. 1. Chemical Structures of Three Complexes 1-3 
Table 1. Crystal Data for Complexes $\mathbf{1},{ }^{1)} \mathbf{2}$ and $\mathbf{3}$

\begin{tabular}{llll}
\hline \hline & \multicolumn{1}{c}{$\mathbf{1}$} & $\mathbf{2}$ & $\mathbf{3}$ \\
\hline Formula & $\mathrm{C}_{12} \mathrm{H}_{12} \mathrm{~N}_{3} \mathrm{O}_{2} \mathrm{CuCl} \cdot 2 \mathrm{H}_{2} \mathrm{O}$ & $2\left(\mathrm{C}_{14} \mathrm{H}_{12} \mathrm{~N}_{3} \mathrm{O}_{2} \mathrm{CuCl}\right) \cdot 7 \mathrm{H}_{2} \mathrm{O}$ & $\mathrm{C}_{12} \mathrm{H}_{12} \mathrm{~N}_{4} \mathrm{O}_{2} \mathrm{CuCl} \cdot \mathrm{H}_{2} \mathrm{O}$ \\
Formula weight & 365.28 & 832.64 & 362.28 \\
Crystal system & Monoclinic & Monoclinic & Monoclinic \\
Space group & $P{ }_{1} / c$ & $P 2 / n$ & $P_{1} / c$ \\
$a(\AA)$ & $10.47(2)$ & $6.837(5)$ & $7.370(6)$ \\
$b(\AA)$ & $18.32(2)$ & $12.21(1)$ & $9.553(9)$ \\
$c(\AA)$ & $7.646(9)$ & $20.25(2)$ & $19.58(2)$ \\
$\alpha\left({ }^{\circ}\right)$ & 90.00 & 90.00 & 90.00 \\
$\beta\left({ }^{\circ}\right)$ & $103.92(5)$ & $95.20(3)$ & $91.01(4)$ \\
$\gamma\left({ }^{\circ}\right)$ & 90.00 & 90.00 & 90.00 \\
$V\left(\AA^{3}\right)$ & $1424(4)$ & $1684(2)$ & $1378(2)$ \\
$Z$ & 4 & 2 & 4 \\
$D_{\text {calc }}\left(\mathrm{g} / \mathrm{cm}{ }^{-3}\right)$ & 1.704 & 1.678 & 1.659 \\
$T(\mathrm{~K})$ & 123.1 & 123.1 & 123.1 \\
$F(000)$ & 748 & 876 & 700 \\
Crystal size $(\mathrm{mm})$ & $0.30 \times 0.10 \times 0.05$ & $0.30 \times 0.08 \times 0.05$ & $0.20 \times 0.10 \times 0.05$ \\
Absorption coefficient $\left(\mathrm{mm}^{-1}\right)$ & 1.740 & 1.493 & 1.784 \\
Reflection measured/unique & $13847 / 3249$ & $15125 / 3852$ & $12528 / 3162$ \\
Observed reflections & 2104 & 1302 & 2324 \\
$R\left(F^{2}>2 \sigma\left(F^{2}\right)\right)$ & 0.030 & 0.068 & 0.028 \\
$R_{\mathrm{w}}\left(F^{2}\right)$ & 0.086 & 0.190 & 0.080 \\
Goodness of fit & 0.943 & 0.934 & 1.056 \\
No. of variables & 294 & 227 & 197 \\
\hline
\end{tabular}

and Takara Bio Inc. (Otsu, Japan), respectively. Gene Ruler 100-bp DNA Lader Plus and Loading Dye solution (Fermentas Co., Ltd.) were obtained from Cosmo Bio Co., Ltd. (Tokyo, Japan).

Preparation of Complexes All single crystals of the complexes were prepared with copper(II) chloride, Gly, bpy, phen, and bpa. The typical syntheses and the results of the elemental analyses are described below.

Preparation of $[\mathbf{C u}(\mathbf{G l y})(\mathrm{bpy}) \mathbf{C l}] \cdot \mathbf{2} \mathrm{H}_{2} \mathrm{O}$ (1) Complex $\mathbf{1}$ was prepared according to the method described previously. ${ }^{1)}$ One hundred and twenty milligrams $(0.76 \mathrm{mmol})$ of bpy was mixed with $130 \mathrm{mg}(0.76 \mathrm{mmol})$ of $\mathrm{CuCl}_{2}$ $2 \mathrm{H}_{2} \mathrm{O}$ in $5 \mathrm{ml} 80 \%(\mathrm{v} / \mathrm{v})$ of methanol-water solution for about $5 \mathrm{~min}$ at room temperature. The aquamarine-colored precipitate appeared after adding copper salt. The precipitate was dried under a vacuum and assumed to be $\left[\mathrm{Cu}(\mathrm{bpy}) \mathrm{Cl}_{2}\right]$. The calculation of the yield of the product as well as the elemental analysis of it were not done. Then, $4.4 \mathrm{mg}(0.015 \mathrm{mmol})$ of the precipitate was reacted with $1.1 \mathrm{mg}(0.015 \mathrm{mmol})$ of Gly in $5 \mathrm{ml}$ of $70 \%(\mathrm{v} / \mathrm{v})$ methanol-water solution for about $30 \mathrm{~min}$ at $343 \mathrm{~K}$, until the volume of the reaction mixture was concentrated to $c a$. $1 \mathrm{ml}$. The concentrated light blue solution was allowed to stand at room temperature for slow evaporation. One week later, yellow-blue prismatic crystals suitable for X-ray diffraction studies were obtained from the mother liquor. Anal. Calcd for $[\mathrm{Cu}(\mathrm{Gly})(\mathrm{bpy}) \mathrm{Cl}]$ $2 \mathrm{H}_{2} \mathrm{O}: \mathrm{C}, 39.461 ; \mathrm{H}, 4.416 ; \mathrm{N}, 11.507$. Found: $\mathrm{C}, 39.321 ; \mathrm{H}, 4.522 ; \mathrm{N}, 11.410$

Preparation of $\left[\mathbf{C u}(\mathrm{Gly})\left(\right.\right.$ phen) $\mathrm{Cl}_{2} \cdot \mathbf{7 H}_{2} \mathrm{O}$ (2) One hundred and fourty milligrams $(0.76 \mathrm{mmol})$ of phen was mixed with $130 \mathrm{mg}(0.76 \mathrm{mmol})$ of $\mathrm{CuCl}_{2} \cdot 2 \mathrm{H}_{2} \mathrm{O}$ in $5 \mathrm{ml}$ of $80 \%(\mathrm{v} / \mathrm{v})$ methanol-water solution for about $5 \mathrm{~min}$ at room temperature. The aquamarine-colored precipitate appeared after adding copper salt. The precipitate was dried under a vacuum and assumed to be $\left[\mathrm{Cu}(\mathrm{phen}) \mathrm{Cl}_{2}\right]$. The calculation of the yield of the product as well as the elemental analysis were not done. Then, $4.7 \mathrm{mg}(0.015 \mathrm{mmol})$ of precipitate was reacted with $1.1 \mathrm{mg}(0.015 \mathrm{mmol})$ of Gly and $1.3 \mathrm{mg}(0.015 \mathrm{mmol})$ of $\mathrm{NaHCO}_{3}$ in $5 \mathrm{ml}$ of water solution for about $30 \mathrm{~min}$ at $343 \mathrm{~K}$, until the volume of the reaction mixture was concentrated to $c a$. $1 \mathrm{ml}$. The concentrated light blue solution was allowed to stand at the room temperature for slow evaporation. Three weeks later, blue prismatic crystals suitable for Xray diffraction studies were obtained from the mother liquor. Anal. Calcd for $[\mathrm{Cu}(\mathrm{Gly})(\mathrm{phen}) \mathrm{Cl}]_{2} \cdot 7 \mathrm{H}_{2} \mathrm{O}: \mathrm{C}, 39.537 ; \mathrm{H}, 4.740 ; \mathrm{N}, 9.822$. Found: $\mathrm{C}, 39.454$; $\mathrm{H}, 4.632 ; \mathrm{N}, 9.924$.

Preparation of $\left[\mathrm{Cu}(\mathrm{Gly})(\mathbf{b p a})\left(\mathrm{H}_{2} \mathbf{O}\right) \mathbf{C l}\right]$ (3) One hundred and thirty milligrams $(0.76 \mathrm{mmol})$ bpa was mixed with $130 \mathrm{mg}(0.76 \mathrm{mmol})$ of $\mathrm{CuCl}_{2} \cdot 2 \mathrm{H}_{2} \mathrm{O}$ in $5 \mathrm{ml}$ of $80 \%(\mathrm{v} / \mathrm{v})$ ethanol-water solution for about $5 \mathrm{~min}$ at room temperature. The dark green precipitate appeared immediately after adding copper salt. The precipitate was dried under a vacuum and assumed to be $\left[\mathrm{Cu}(\mathrm{bpa}) \mathrm{Cl}_{2}\right]$. The calculation of the yield of the product and the elemental analysis were not done. Then, $4.6 \mathrm{mg}(0.015 \mathrm{mmol})$ of precipitate was mixed with $1.1 \mathrm{mg}(0.015 \mathrm{mmol})$ of Gly in $5 \mathrm{ml}$ of degassed water solu- tion, and the $\mathrm{pH}$ of the reaction mixture was adjusted to $5-6$ using $20 \mathrm{~mm}$ $\mathrm{NaOH}$. The reaction was continued for about $30 \mathrm{~min}$ at $343 \mathrm{~K}$, until the volume of the reaction mixture was concentrated to $c a .1 \mathrm{ml}$. The concentrated light green solution was allowed to stand at room temperature for slow evaporation. Four weeks later, blue prismatic crystals suitable for X-ray diffraction studies were obtained from mother liquor. Anal. Calcd for [Cu(Gly)(bpa) $\left.\left(\mathrm{H}_{2} \mathrm{O}\right) \mathrm{Cl}\right]: \mathrm{C}, 39.899 ; \mathrm{H}, 3.906 ; \mathrm{N}, 15.514$. Found: C, 39.788; $\mathrm{H}, 3.812 ; \mathrm{N}, 15.513$.

X-Ray Crystal Analysis The X-ray measurements were performed on a Rigaku RAXIS RAPID diffractometer with a graphite monochromatized Mo $K \alpha$ radiation $(50 \mathrm{kV}-100 \mathrm{~mA} ; \lambda=0.71069 \AA)$ using the $\omega$ scan mode at $123 \mathrm{~K}$. A summary of the crystallographic data and structure refinements is given in Table 1. The data were corrected for Lorentz and polarization effects. The structure was solved by direct methods ${ }^{20)}$ using the Crystal Structure $^{21)}$ software package. The refinement was performed using SHELXL97. ${ }^{22)} \mathrm{All} \mathrm{H}$ atoms except those of water molecules were located from difference Fourier maps, placed at idealized positions, and treated as riding, with a $\mathrm{C}-\mathrm{H}$ distance of 0.93 and $U_{\text {iso }}(\mathrm{H})$ values equal to $1.2 U_{\text {eq }}(\mathrm{C})\left(U_{\text {eq }}\right.$ is the equivalent isotropic displacement parameter for the pivot atom.).

The function of $\sum w\left(F_{\mathrm{o}}^{2}-F_{\mathrm{c}}^{2}\right)^{2}$ was minimized by using the weight scheme of $w=1 /\left[\sigma^{2}\left(F_{\mathrm{o}}^{2}\right)+(a P)^{2}+b P\right]$, where $P=\left(F_{\mathrm{o}}^{2}+2 F_{\mathrm{c}}^{2}\right) / 3$. Final $R$ $\left.\left[=\sum\left(\left|F_{\mathrm{o}}\right|-\left|F_{\mathrm{c}}\right|\right) / \sum\left|F_{\mathrm{o}}\right|\right]\right], R_{\mathrm{w}}\left[=\left(\sum w\left(\left|F_{\mathrm{o}}\right|-\left|F_{\mathrm{c}}\right|\right)^{2} / \sum w\left|F_{\mathrm{o}}\right|^{2}\right)^{\mathrm{o} / 2}\right]$, and $S$ (goodness of fit) $\left[=\left(\sum w\left(\left|F_{\mathrm{o}}\right|-\left|F_{\mathrm{c}}\right|\right)^{2} /(M-N)^{1 / 2}\right)\right.$, where $M=$ no. of reflections and $N=$ no. of variables used for the refinement] values are given in Table 1. Anisotropic displacement coefficients were refined for all nonhydrogen atoms. Selected bond distances and angles are listed in Tables $2-4$ for complexes $\mathbf{1}-\mathbf{3}$, respectively. The distance between the centers of gravities $(\mathrm{Cg}-\mathrm{Cg}$ distance $)$ were calculated using PLATON. ${ }^{23)}$ The detailed H-bond data are summarized in Table 5 .

The final atomic coordinates, anisotropic displacement coefficients, bond lengths, bond angles, torsion angles of non-H atoms, and the atomic coordinates of $\mathrm{H}$ atoms have been deposited in the Cambridge Crystallographic Data Centre, Cambridge University Chemical Laboratory, Cambridge, U.K. (CCDC No. 289755 for [Cu(Gly)bpy)Cl] $\cdot 2 \mathrm{H}_{2} \mathrm{O}$ (1), CCDC 628028 for $\left[\mathrm{Cu}(\mathrm{Gly})(\mathrm{phen}) \mathrm{Cl}_{2} \cdot 7 \mathrm{H}_{2} \mathrm{O}\right.$ (2), and $\mathrm{CCDC} 628029$ for $\left[\mathrm{Cu}(\mathrm{Gly})(\mathrm{bpa})\left(\mathrm{H}_{2} \mathrm{O}\right) \mathrm{Cl}\right](\mathbf{3})$

DNA-Binding Experiments The binding experiment of the complexes to CT DNA was studied using the fluorescence method. Competitive binding studies were performed by measuring the emission of ethidium bromide (EB) bound to DNA which shows the enhanced emission intensity due to its intercalative binding to DNA. ${ }^{24,25)}$ The competitive binding of the complexes to the DNA reduces the emission intensity of EB with either a displacement of the bound EB from the bound to the free state or the bound complex quenching the emission. ${ }^{26,27)}$ 
Fluorescence measurements were performed using an Hitachi-850 spectrofluorometer equipped with a temperature control bath. All the fluorescence measurements were taken at $\lambda_{\text {ex }}$ of $545 \mathrm{~nm}$ and $\lambda_{\text {em }}$ of $600 \mathrm{~nm}$ at $25 \pm 0.1^{\circ} \mathrm{C}$.

In a typical binding experiment, $2 \mu$ solution of $1.45 \mathrm{~mm}$ EB was added to a volume of $300 \mu \mathrm{l}$ of $100 \mu \mathrm{M}$ CT DNA solution. All the fluorescence measurements were taken at $\lambda_{\text {ex }}$ of $545 \mathrm{~nm}$ and $\lambda_{\text {em }}$ of $600 \mathrm{~nm}$. Aliquots of $3 \mathrm{~mm}$ of a solution of the complexes in distilled water were added to the EB-DNA solution. After the mixtures were incubated overnight, their fluorescence intensity was measured after each addition. The fluorescence intensities were plotted against the complex concentration to yield a slope that showed the relative extent of binding of the complexes to DNA. A control experiment was also done with the EB in the absence of DNA.

CD Measurements CD spectra of the CT DNA were measured using a JASCO J-710 spectropolarimeter erquipped with a Peltier temperature control device at $25 \pm 0.1^{\circ} \mathrm{C}$. All experiments were done using a quartz cell of $1 \mathrm{~cm}$ pathlength. Each $\mathrm{CD}$ spectrum was recorded after averaging over at least 5 accumulations using a scan speed of $100 \mathrm{~nm} \mathrm{~min}^{-1}$.

DNA Cleavage Experiments The cleavage experiments were per-

Table 2. Bond Distances $(\AA)$ and Angles $\left({ }^{\circ}\right)$ for Complex $\mathbf{1}^{1}$

\begin{tabular}{|c|c|c|c|}
\hline \multicolumn{4}{|l|}{ Bond distances } \\
\hline $\mathrm{Cu} 1-\mathrm{O} 1$ & $1.957(2)$ & $\mathrm{N} 1-\mathrm{C} 5$ & $1.354(4)$ \\
\hline $\mathrm{Cu} 1-\mathrm{O} 2 *$ & $2.748(2)$ & $\mathrm{N} 2-\mathrm{C} 6$ & $1.347(3)$ \\
\hline $\mathrm{Cu} 1-\mathrm{Cl1}$ & $2.635(5)$ & $\mathrm{N} 2-\mathrm{C} 10$ & $1.337(3)$ \\
\hline $\mathrm{Cu} 1-\mathrm{N} 1$ & $2.002(2)$ & N3-C11 & $1.474(4)$ \\
\hline $\mathrm{Cu} 1-\mathrm{N} 2$ & $1.999(2)$ & $\mathrm{O} 1-\mathrm{C} 12$ & $1.274(4)$ \\
\hline $\mathrm{Cu} 1-\mathrm{N} 3$ & $2.006(2)$ & $\mathrm{O} 2-\mathrm{C} 12$ & $1.242(3)$ \\
\hline $\mathrm{N} 1-\mathrm{C} 1$ & $1.338(3)$ & $\mathrm{C} 11-\mathrm{C} 12$ & $1.520(4)$ \\
\hline \multicolumn{4}{|l|}{ Bond angles } \\
\hline $\mathrm{N} 1-\mathrm{Cu} 1-\mathrm{N} 3$ & $98.49(9)$ & $\mathrm{N} 3-\mathrm{Cu} 1-\mathrm{O} 2 *$ & $80.4(1)$ \\
\hline $\mathrm{N} 1-\mathrm{Cu} 1-\mathrm{N} 2$ & $84.52(9)$ & N3-Cu1-O1 & $84.52(9)$ \\
\hline $\mathrm{N} 1-\mathrm{Cu} 1-\mathrm{C} 11$ & $92.01(9)$ & $\mathrm{O} 1-\mathrm{Cu} 1-\mathrm{Cl1}$ & $98.04(9)$ \\
\hline $\mathrm{N} 1-\mathrm{Cu} 1-\mathrm{O} 1$ & $169.25(7)$ & $\mathrm{O} 1-\mathrm{Cu} 1-\mathrm{O} 2 *$ & $82.3(1)$ \\
\hline $\mathrm{N} 1-\mathrm{Cu} 1-\mathrm{O} 2 *$ & $88.0(1)$ & $\mathrm{C} 1-\mathrm{N} 1-\mathrm{Cu} 1$ & $126.7(2)$ \\
\hline $\mathrm{N} 2-\mathrm{Cu} 1-\mathrm{N} 3$ & $165.12(8)$ & $\mathrm{C} 5-\mathrm{N} 1-\mathrm{Cu} 1$ & $114.6(1)$ \\
\hline $\mathrm{N} 2-\mathrm{Cu} 1-\mathrm{O} 1$ & $93.04(8)$ & $\mathrm{C} 6-\mathrm{N} 2-\mathrm{Cu} 1$ & $114.5(2)$ \\
\hline $\mathrm{N} 2-\mathrm{Cu} 1-\mathrm{Cl} 1$ & $100.1(1)$ & $\mathrm{C} 10-\mathrm{N} 2-\mathrm{Cu} 1$ & $125.8(2)$ \\
\hline $\mathrm{N} 2-\mathrm{Cu} 1-\mathrm{O} 2 *$ & $84.8(1)$ & $\mathrm{C} 11-\mathrm{N} 3-\mathrm{Cu} 1$ & $108.7(2)$ \\
\hline N3-Cu1-Cl1 & $94.8(1)$ & $\mathrm{C} 12-\mathrm{O} 1-\mathrm{Cu} 1$ & $115.5(2)$ \\
\hline
\end{tabular}

Symmetry code: $(*)+1-x,+1-y,+1-z$.
Table 3. Bond Distances $(\AA)$ and Angles $\left({ }^{\circ}\right)$ for Complex 2

\begin{tabular}{lrlr}
\hline \hline Bond distances & & & \\
Cu1-O1 & $1.950(4)$ & N2-C6 & $1.348(8)$ \\
Cu1-Cl1 & $2.573(2)$ & N2-C10 & $1.330(9)$ \\
Cu1-N1 & $2.015(5)$ & N3-C14 & $1.481(8)$ \\
Cu1-N2 & $2.014(5)$ & O1-C13 & $1.285(7)$ \\
Cu1-N3 & $2.006(5)$ & O2-C13 & $1.231(8)$ \\
N1-C1 & $1.341(8)$ & C13-C14 & $1.527(9)$ \\
N1-C5 & $1.362(7)$ & & \\
Bond angles & & & \\
N1-Cu1-N2 & $82.0(2)$ & N3-Cu1-O1 & $84.0(2)$ \\
N1-Cu1-N3 & $98.1(2)$ & O1-Cu1-Cl1 & $94.8(2)$ \\
N1-Cu1-C11 & $96.8(2)$ & C1-N1-Cu1 & $130.2(4)$ \\
N1-Cu1-O1 & $167.5(2)$ & C5-N1-Cu1 & $112.7(4)$ \\
N2-Cu1-N3 & $162.9(2)$ & C6-N2-Cu1 & $112.8(4)$ \\
N2-Cu1-O1 & $92.4(2)$ & C10-N2-Cu1 & $128.4(4)$ \\
N2-Cu1-C11 & $96.0(2)$ & C14-N3-Cu1 & $107.0(4)$ \\
N3-Cu1-Cl1 & $101.0(2)$ & C13-O1-Cu1 & $114.7(4)$ \\
& & &
\end{tabular}

Table 4. Bond Distances $(\AA)$ and Angles $\left({ }^{\circ}\right)$ for Complex 3

\begin{tabular}{|c|c|c|c|}
\hline \multicolumn{4}{|l|}{ Bond distances } \\
\hline $\mathrm{Cu} 1-\mathrm{O} 1$ & $1.978(2)$ & $\mathrm{O} 2-\mathrm{C} 11$ & $1.241(3)$ \\
\hline $\mathrm{Cu} 1-\mathrm{Cl1}$ & $2.642(3)$ & $\mathrm{C} 11-\mathrm{C} 12$ & $1.524(3)$ \\
\hline $\mathrm{Cu} 1-\mathrm{O} 3$ & $2.978(2)$ & $\mathrm{N} 1-\mathrm{C} 1$ & $1.355(3)$ \\
\hline $\mathrm{Cu} 1-\mathrm{N} 1$ & $1.996(2)$ & $\mathrm{N} 1-\mathrm{C} 5$ & $1.348(3)$ \\
\hline $\mathrm{Cu} 1-\mathrm{N} 2$ & $1.979(2)$ & $\mathrm{N} 2-\mathrm{C} 6$ & $1.339(3)$ \\
\hline $\mathrm{Cu} 1-\mathrm{N} 4$ & $2.030(2)$ & $\mathrm{N} 2-\mathrm{C} 10$ & $1.362(3)$ \\
\hline $\mathrm{O} 1-\mathrm{C} 11$ & $1.274(3)$ & $\mathrm{N} 4-\mathrm{C} 12$ & $1.481(3)$ \\
\hline \multicolumn{4}{|l|}{ Bond angles } \\
\hline $\mathrm{N} 1-\mathrm{Cu} 1-\mathrm{N} 2$ & $89.14(7)$ & $\mathrm{N} 4-\mathrm{Cu} 1-\mathrm{O} 3$ & $81.47(8)$ \\
\hline $\mathrm{N} 1-\mathrm{Cu} 1-\mathrm{N} 4$ & $99.26(7)$ & $\mathrm{O} 1-\mathrm{Cu} 1-\mathrm{Cl1}$ & $94.90(7)$ \\
\hline $\mathrm{N} 1-\mathrm{Cu} 1-\mathrm{Cl1}$ & $93.32(7)$ & $\mathrm{O} 1-\mathrm{Cu} 1-\mathrm{O} 3$ & $93.39(8)$ \\
\hline $\mathrm{N} 1-\mathrm{Cu} 1-\mathrm{O} 1$ & $171.58(7)$ & $\mathrm{C} 1-\mathrm{N} 1-\mathrm{Cu} 1$ & $118.6(1)$ \\
\hline $\mathrm{N} 1-\mathrm{Cu} 1-\mathrm{O} 3$ & $78.60(8)$ & $\mathrm{C} 5-\mathrm{N} 1-\mathrm{Cu} 1$ & $123.4(1)$ \\
\hline $\mathrm{N} 2-\mathrm{Cu} 1-\mathrm{N} 4$ & $167.89(7)$ & $\mathrm{C} 5-\mathrm{N} 3-\mathrm{C} 6$ & $128.7(2)$ \\
\hline $\mathrm{N} 2-\mathrm{Cu} 1-\mathrm{Cl} 1$ & $93.45(6)$ & C6-N2-Cu1 & $123.7(1)$ \\
\hline $\mathrm{N} 2-\mathrm{Cu} 1-\mathrm{O} 1$ & $88.54(7)$ & $\mathrm{C} 10-\mathrm{N} 2-\mathrm{Cu} 1$ & $117.4(1)$ \\
\hline $\mathrm{N} 2-\mathrm{Cu} 1-\mathrm{O} 3$ & $91.76(7)$ & $\mathrm{C} 12-\mathrm{N} 4-\mathrm{Cu} 1$ & $104.4(1)$ \\
\hline $\mathrm{N} 4-\mathrm{Cu} 1-\mathrm{O} 1$ & $81.89(7)$ & $\mathrm{C} 11-\mathrm{O} 1-\mathrm{Cu} 1$ & $112.5(1)$ \\
\hline $\mathrm{N} 4-\mathrm{Cu} 1-\mathrm{Cl} 1$ & $94.74(7)$ & & \\
\hline
\end{tabular}

Table 5. Hydrogen Bond Distances $(\AA)$ and Angles $\left({ }^{\circ}\right)$ for Complexes $\mathbf{1}^{1)}-\mathbf{3}$

\begin{tabular}{|c|c|c|c|c|c|}
\hline Donor (D-H) & Acceptor (A) & Sym.code of A & $\mathrm{D} \cdots \mathrm{A}(\AA)$ & $\mathrm{H} \cdots \mathrm{A}(\AA)$ & $\mathrm{D}-\mathrm{H} \cdots \mathrm{A}\left({ }^{\circ}\right)$ \\
\hline \multicolumn{6}{|l|}{ Complex 1} \\
\hline N3 & $\mathrm{Cl1}$ & $+x, 1 / 2-y,-1 / 2+z$ & $3.453(7)$ & 2.60 & 157 \\
\hline N3 & $\mathrm{O} 3$ & $+x, 1 / 2-y,-1 / 2+z$ & $3.227(7)$ & 2.40 & 153 \\
\hline $\mathrm{O} 3$ & $\mathrm{O} 2$ & $1-x,-1 / 2+y, 3 / 2-z$ & $2.799(3)$ & 1.94 & 148 \\
\hline $\mathrm{O} 3$ & $\mathrm{Cl1}$ & $+x, 1 / 2-y,-1 / 2+z$ & $3.199(7)$ & 2.26 & 168 \\
\hline $\mathrm{O} 4$ & $\mathrm{Cl1}$ & & $3.137(7)$ & 2.15 & 172 \\
\hline $\mathrm{O} 4$ & $\mathrm{Cl1}$ & $+x, 1 / 2-y,-1 / 2+z$ & $3.194(7)$ & 2.33 & 145 \\
\hline \multicolumn{6}{|l|}{ Complex 2} \\
\hline $\mathrm{N} 3$ & $\mathrm{O} 3$ & $3 / 2-x,-1 / 2+y, 1 / 2-z$ & $3.000(8)$ & 2.12 & 165 \\
\hline N3 & $\mathrm{O} 2$ & $1 / 2-x,-1 / 2+y, 1 / 2-z$ & $3.031(7)$ & 2.36 & 131 \\
\hline $\mathrm{O} 3$ & $\mathrm{Cl1}$ & & $3.216(6)$ & 2.16 & 178 \\
\hline $\mathrm{O} 3$ & O6 & & $2.743(8)$ & 1.86 & 179 \\
\hline $\mathrm{O} 4$ & O6 & & $2.751(12)$ & 1.69 & 164 \\
\hline $\mathrm{O} 4$ & O5 & $1-x, 2-y, 1-z$ & $3.00(1)$ & 2.37 & 152 \\
\hline O5 & $\mathrm{O} 3$ & $-1+x,+y,+z$ & $2.827(8)$ & 1.87 & 173 \\
\hline O5 & $\mathrm{O} 4$ & & $2.59(1)$ & 2.59 & 179 \\
\hline O6 & $\mathrm{C} 11$ & $3 / 2-x, 1 / 2+y, 1 / 2-z$ & $3.099(5)$ & 2.06 & 176 \\
\hline O6 & $\mathrm{O} 1$ & & $2.889(7)$ & 2.89 & 175 \\
\hline \multicolumn{6}{|l|}{ Complex 3} \\
\hline N3 & $\mathrm{O} 3$ & $1-x, 1-y, 2+z$ & $2.937(4)$ & 2.17 & 149 \\
\hline $\mathrm{N} 4$ & $\mathrm{O} 1$ & $1-x,-1 / 2-y, 3 / 2-z$ & $3.278(2)$ & 2.44 & 146 \\
\hline N4 & $\mathrm{Cl1}$ & $2-x,-1 / 2-y, 3 / 2-z$ & $3.297(2)$ & 2.54 & 154 \\
\hline $\mathrm{O} 3$ & $\mathrm{Cl1}$ & $-1+x,+y,+z$ & $3.224(2)$ & 2.33 & 171 \\
\hline $\mathrm{O} 3$ & $\mathrm{O} 2$ & $1-x,-1 / 2-y, 3 / 2-z$ & $2.782(2)$ & 1.90 & 179 \\
\hline
\end{tabular}


formed using SC DNA in $10 \mathrm{~mm}$ Tris- $\mathrm{HCl}$ buffer, $\mathrm{pH} 7.4$, containing $50 \mathrm{~mm}$ $\mathrm{NaCl}^{2,3)}$ The reaction mixtures were prepared as follows: both $4 \mu 1$ of $7 \mathrm{~mm}$ $\mathrm{H}_{2} \mathrm{O}_{2}$ and $4 \mu \mathrm{l}$ of $7 \mathrm{~mm}$ ascorbic acid were added to a mixture of $20 \mu \mathrm{l}$ of SC DNA $(0.05 \mu \mathrm{g} / \mu \mathrm{l})$ and $6 \mu \mathrm{l}$ of $300 \mu \mathrm{m}$ complexes followed by dilution with Tris- $\mathrm{HCl}$ buffer to a total volume of $40 \mu \mathrm{l}$. The final concentration of the complexes was $45 \mu \mathrm{M}$, and that of $\mathrm{H}_{2} \mathrm{O}_{2}$ and ascorbic acid were $525 \mu \mathrm{M}$. The reactions were performed after incubating the reaction mixture at $25^{\circ} \mathrm{C}$ for $1 \mathrm{~h}$ in the presence and/or absence of the complexes. For the experiments on the concentration dependence of the complexes, $3 \mu \mathrm{l}$ of $\mathrm{H}_{2} \mathrm{O}_{2}, 3 \mu \mathrm{l}$ of $\mathrm{H}_{2} \mathrm{O}_{2}$, and $2-10 \mu \mathrm{l}$ of the complexes were used in the above reaction mixture of $40 \mu$ l. The final concentrations of the complexes were changed from 15 to $75 \mu \mathrm{M}$, and that of $\mathrm{H}_{2} \mathrm{O}_{2}$ and ascorbic acid was $525 \mu \mathrm{M}$.

A loading buffer $(3 \mu \mathrm{l})$ containing $0.03 \%$ bromophenol blue, $0.03 \% \mathrm{xy}-$ lene cyanol, and $60 \%$ glycerol was added to $20 \mu$ of the reaction mixtures and electrophoresis was performed at $50 \mathrm{~V}$ for $70 \mathrm{~min}$ in Tris-acetate-EDTA (TAE) buffer, $\mathrm{pH} 8.1$, using $1 \%$ agarose gel. After electrophresis, the agarose gel was dyed in EB solution $(0.5 \mu \mathrm{g} / \mathrm{ml})$.

A agarose gel electrophoresis was performed using COSMO BIO Mupid2. The cleavage of SC DNA was monitored by photographing the fluorescence of intercalated EB using an Amersham Pharmacia Biotech Image Master VDS-CL illuminator.

The concentration of CT DNA was determined by measuring the absorption intensity at $260 \mathrm{~nm}$ with the molar extinction coefficient value of $6600 \mathrm{M}^{-1} \mathrm{~cm}^{-1}$ in Tris- $\mathrm{HCl} / \mathrm{NaCl}$ buffer, $\mathrm{pH} \mathrm{7.4.}{ }^{28)}$ The concentration of SC DNA was calculated from the contents of the sample vials $(0.5 \mu \mathrm{g} / \mu \mathrm{l})$. Elemental analysis was done on a Yanaco CHN Coder MT-3.

\section{Results and Discussion}

Crystal Structures In complex $\mathbf{1},{ }^{1)}$ shown in Fig. 2, the $\mathrm{Cu}$ (II) atom has a distorted octahedral six-coordination geometry and is bonded to two heterocyclic $\mathrm{N}$ atoms, one amino $\mathrm{N}$ atom, and one carboxylate $\mathrm{O}$ atom from Gly in a equatorial plane, and one $\mathrm{Cl}$ atom and one carboxylate $\mathrm{O}$ atom of the neighboring Gly ligand in the axial position. In the square-planar coordination, atom $\mathrm{Cu} 1$ deviates by $0.2141(11) \AA$ from the mean plane through the O1, N1, N2, and $\mathrm{N} 3$ atoms. The five-membered chelate rings, $\mathrm{Cu} 1-\mathrm{N} 1-$ C5-C6-N2 and Cu1-N3-C11-C12-O1, are formed with the bpy and Gly ligand, respectively. These rings are slightly twisted with the dihedral angle of $16.9(1)^{\circ}$. This is caused by the short contact between the $\mathrm{H}$ atom of $\mathrm{C} 1$ and the $\mathrm{H}$ atom of the amino group. The two pyridine rings of bpy are slightly twisted with the dihedral angle of $2.7(3)^{\circ}$. Gly takes an eclipsed conformation with the torsion angle of N3-C11-C12-O3, 8.5(9) ${ }^{\circ}$.

In the crystal packing of $\mathbf{1}$, the complex forms essentially a dinuclear complex, in which two neighboring complexes are bridged by the coordinated carboxylete $\mathrm{O}$ atoms as shown in Fig. 3a, in which typical $\pi-\pi$ interaction is present between bpy ligands at the symmetry codes of $(+x,+y,+z)$ and $(2-x,-y, 1-z)$. The distance between $\mathrm{Cg} 1(\mathrm{~N} 1 / \mathrm{C} 1-\mathrm{C} 5)$ [symmetry code: $(+x,+y,+z)]$ and $\mathrm{Cg} 2(\mathrm{~N} 2 / \mathrm{C} 6-\mathrm{C} 10)$ [symmetry code: $(2-x,-y, 1-z)]$ is $4.05(6) \AA$, where $\mathrm{Cg}$ indicates the center of the gravity $(\mathrm{Cg})$ of the ring. The stacking layer arrays in the diagonal direction of the $b-c$ axes. The hydrogen bonding in $\mathbf{1}$ is shown in Fig. $3 \mathrm{~b}$, and the complex molecules are connected by two hydrated water molecules, $\mathrm{O} 3$ and $\mathrm{O} 4$, forming $\mathrm{O} 2 \cdots \mathrm{H} 13-\mathrm{O}-\mathrm{H} 14 \cdots \mathrm{Cl}$ and $\mathrm{Cl1} \cdots \mathrm{H} 15-\mathrm{O}-\mathrm{H} 16 \cdots \mathrm{Cl}$ bridges. The $\mathrm{Cl}$ atom acts as the acceptor of the four hydrogen bonds. The complex molecules are connected to each other by the all of the available $\mathrm{H}$ bonds. The overall complex molecules are stabilized by the $\mathrm{H}$-bond network together with the $\pi-\pi$ interaction.

In complex 2 shown in Fig. 4, the $\mathrm{Cu}(\mathrm{II})$ atom has a dis-

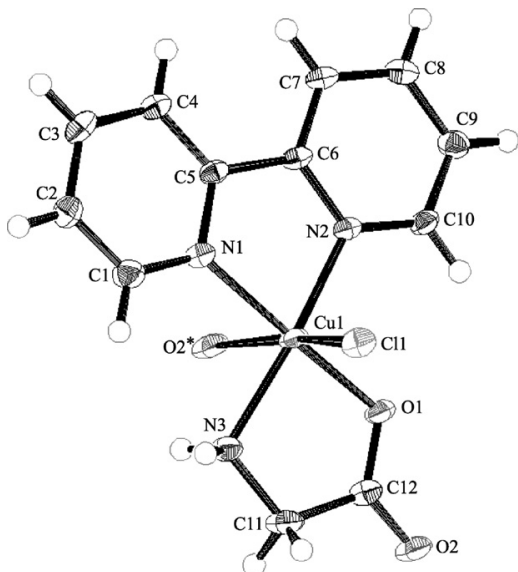

Fig. 2. ORTEP II Drawing of Complex 1, ${ }^{1)}$ Showing 50\% Probability Displacement Ellipsoids

The water molecules involved in the unit cell are omitted for the clarification of the basic $\mathrm{Cu}(\mathrm{II})$ coordination geometry [symmetry code: $(*) 1-x, 1-y, 1-z$ ].

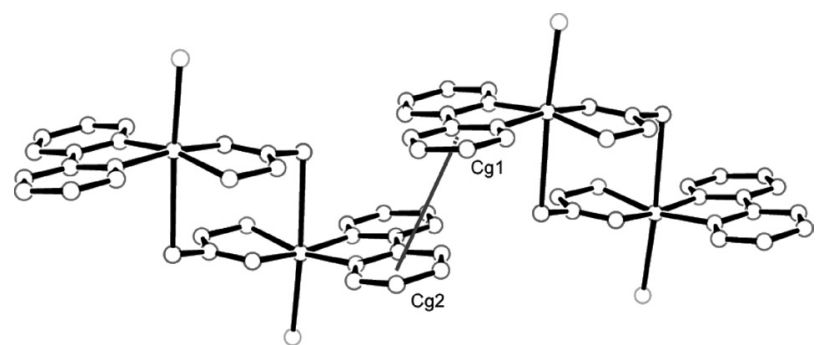

Fig. 3a. View of the $\pi-\pi$ Interaction between bpy Ligands, $\mathrm{Cg} 1(\mathrm{~N} 1 / \mathrm{C} 1-\mathrm{C} 5)$ and $\mathrm{Cg} 2(\mathrm{~N} 2 / \mathrm{C} 6-\mathrm{C} 10)$ [Symmetry Code: $2-x,-y, 1-z$ ], Where $\mathrm{Cg}$ Indicates the Center of Gravity of the Ring

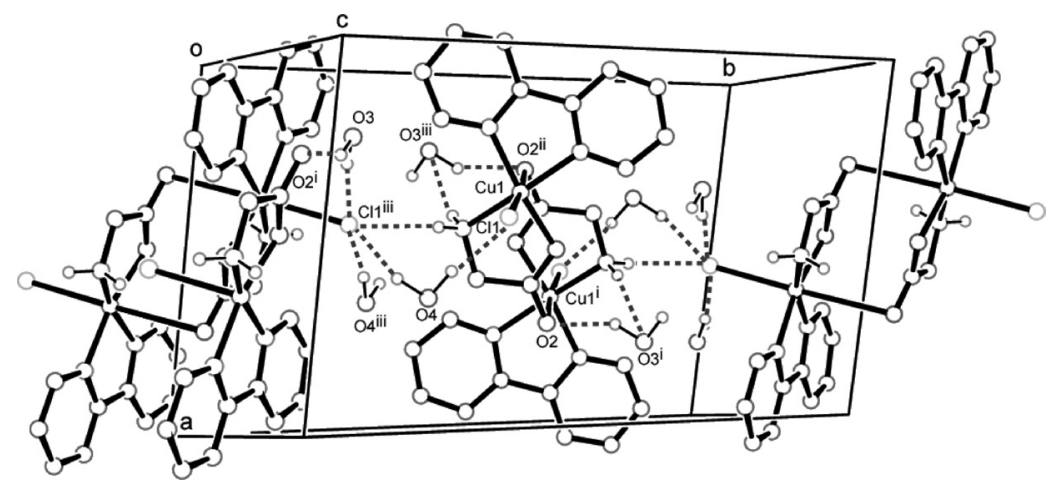

Fig. 3b. View of the Packing Pattern in Complex 1 Including H-Bonds Indicated with Dashed Lines [Symmetry Codes: (i) $-x, 1 / 2+y, 1 / 2-z$; (ii) $-x,-y,-z$; (iii) $x, 1 / 2-y, 1 / 2+z]$ 


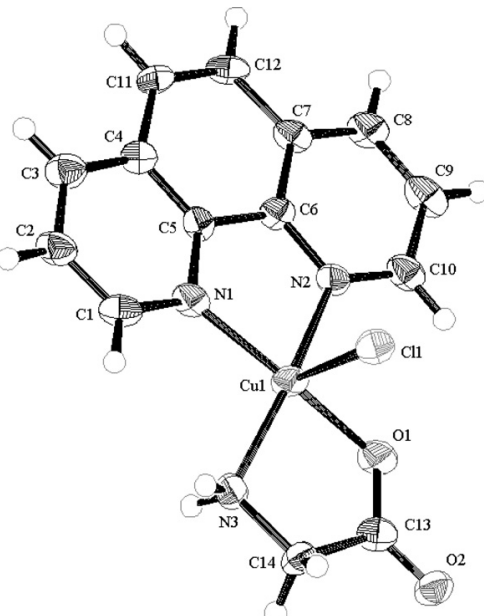

Fig. 4. ORTEP II Drawing of Complex 2, Showing 50\% Probability Displacement Ellipsoids

The water molecules involved in the unit are omitted for the clarification of the basic $\mathrm{Cu}$ (II) coordination geometry.

torted square-pyramidal five coordination geometry. The $\mathrm{Cu}$ (II) atom is bonded to two $\mathrm{N}$ atoms from the bidentate phen ligand and one carboxylate $\mathrm{O}$ atom and one $\mathrm{N}$ atom from Gly in the equatorial plane and one $\mathrm{Cl}$ atom in the axial position. The $\mathrm{Cul}$ atom deviates from the mean square plane $(\mathrm{N} 1 / \mathrm{N} 2 / \mathrm{O} 1 / \mathrm{N} 3)$ toward the $\mathrm{Cl}$ atom by the upper distance of $0.2495(3) \AA$, similar to complex 1. The five-membered chelate rings, $\mathrm{Cu} 1-\mathrm{N} 1-\mathrm{C} 5-\mathrm{C} 6-\mathrm{N} 2$ and $\mathrm{Cu} 1-\mathrm{N} 3-\mathrm{C} 14-$ C13-O1, are formed with the phen and Gly ligands, respectively. These two rings are slightly twisted with the dihedral angle of $19.6(2)^{\circ}$. This is caused by the short contact between the $\mathrm{H}$ atom of $\mathrm{C} 1$ and the $\mathrm{H}$ atom of the amino group. The phen ring is almost planar. The Gly ligand takes an eclipsed conformation with the torsion angle of $\mathrm{N} 3-\mathrm{C} 11-\mathrm{C} 12-\mathrm{O} 3$ of $8.5(9)^{\circ}$. The two types of structure of $\mathrm{Cu}$ (II) complexes of Gly with phen have been reported to be a monohydrate complex, $[\mathrm{Cu}(\mathrm{Gly})($ phen $) \mathrm{Cl}] \cdot \mathrm{H}_{2} \mathrm{O}^{18)}$ and a trihydrate one, $[\mathrm{Cu}(\mathrm{Gly})($ phen $) \mathrm{Cl}] \cdot 3 \mathrm{H}_{2} \mathrm{O} .{ }^{19)}$ Their overall structures are essentially the same as that of $\mathbf{2}$, although the geometrical parameters are slightly different from that of 2 .

In the packing of $\mathbf{2}$, the $\pi-\pi$ interaction is present between phen rings as well as between the phen ring and the five-memberd chelate rings with the distances between $\mathrm{Cg} 1(\mathrm{~N} 1 / \mathrm{C} 1-\mathrm{C} 5)$ and $\mathrm{Cg} 2(\mathrm{~N} 2 / \mathrm{C} 6-\mathrm{C} 10)$ [symmetry code: $(1-x, 1-y, 1-z)]$ of $3.56(10) \AA$, and $\mathrm{Cg} 3(\mathrm{Cu} 1 / \mathrm{N} 1 / \mathrm{C} 5 /$ $\mathrm{C} 6 / \mathrm{N} 2)$ and $\mathrm{Cg} 4(\mathrm{C} 4-\mathrm{C} 7 / \mathrm{C} 11 / \mathrm{C} 12)$ [symmetry code: $(1-x, 1-y, 1-z)]$ of $3.46(10) \AA$, as shown in Fig. 5a. The hydrogen-bond networks are also indicated by dashed lines in Fig. 5b, in which the water $\mathrm{O} 4$ atom is disordered and refined as half-occupancy. The complex molecules are connected to each other by the available H-bonds. The overall complex molecules are stabilized by the H-bond network together with the $\pi-\pi$ interaction.

The molecular structure of complex 3 is shown in Fig. 6. The $\mathrm{Cu}$ (II) atom has a distorted octahedral six coordination geometry. The $\mathrm{Cu}$ (II) atom is bonded to two $\mathrm{N}$ atoms from the bidentate bpa ligand and one carboxylate $\mathrm{O}$ atom and one $\mathrm{N}$ atom from Gly in the equatorial plane, and one $\mathrm{Cl}$ atom and one water $\mathrm{O}$ atom in the axial positions. In the squareplanar coordination, atom Cu1 deviates by $0.1419(3) \AA$ from

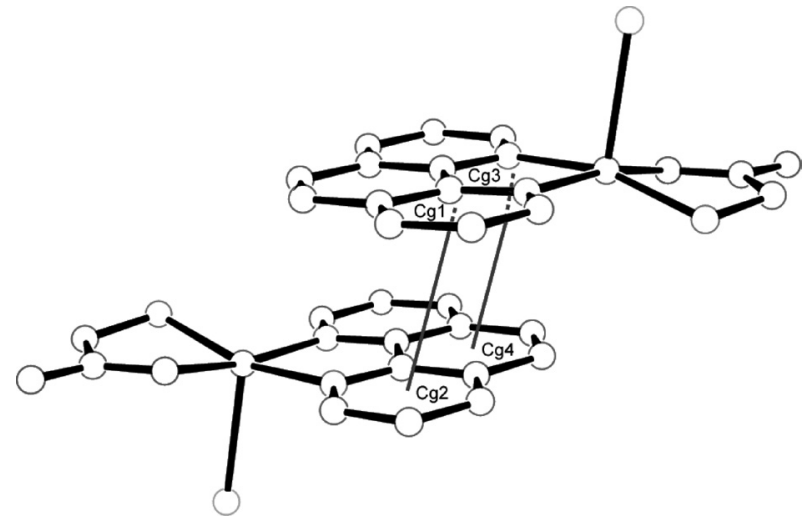

Fig. 5a. View of the $\pi-\pi$ Interaction between Adjacent Complexes, between $\mathrm{Cg} 1(\mathrm{~N} 1 / \mathrm{C} 1-\mathrm{C} 5)$ and $\mathrm{Cg} 2(\mathrm{~N} 2 / \mathrm{C} 6-\mathrm{C} 10)$ [Symmetry Code: $1-x$, $1-y, 1-z]$, and between $\mathrm{Cg} 3(\mathrm{Cu} 1 / \mathrm{N} 1 / \mathrm{C} 5 / \mathrm{C} 6 / \mathrm{N} 2)$ and $\mathrm{Cg} 4(\mathrm{C} 4-\mathrm{C} 7 / \mathrm{C} 11 /$ C12) [Symmetry Code: $1-x, 1-y, 1-z]$

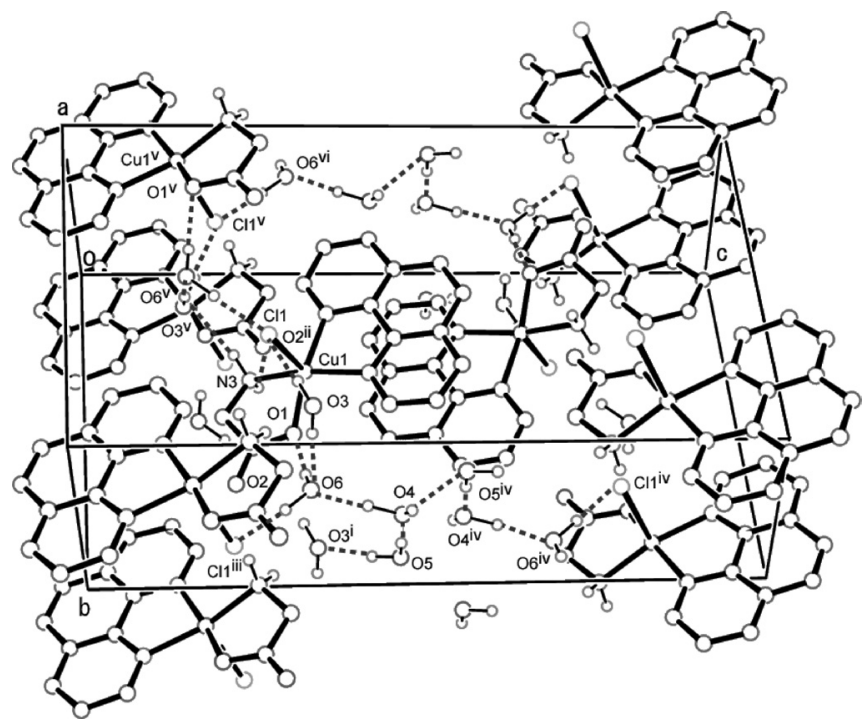

Fig. 5b. View of the Packing Pattern in Complex 2 Including H-Bonds Indicated by Dashed Lines [Symmetry Codes: (i) $1 / 2-x, 1 / 2+y, 1 / 2-z$; (ii) $-x,-y,-z]$

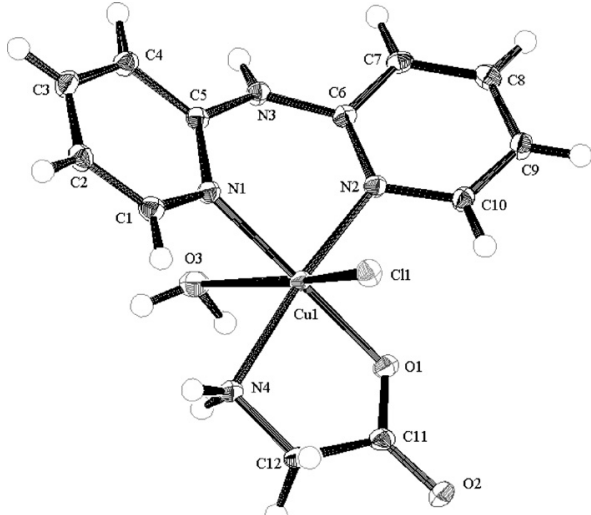

Fig. 6. ORTEP II Drawing of Complex 3, Showing 50\% Probability Displacement Ellipsoids

The water molecules involved in the unit are omitted for the clarification of the basic $\mathrm{Cu}(\mathrm{II})$ coordination geometry.

the mean plane through the $\mathrm{O} 1, \mathrm{~N} 1, \mathrm{~N} 2$, and N4 atoms. The six- and five-membered chelate rings, Cu1-N1-C5-N3C6-N2 and Cu1-N4-C12-C11-O1, were formed with the 
bpa and Gly ligands, respectively. These two rings are slightly twisted with the dihedral angle of $16.9(1)^{\circ}$. This is caused by the short contact between the $\mathrm{H}$ atom of $\mathrm{C} 1$ and the $\mathrm{H}$ atom of the amino group. The two pyridine rings of the bpa ligand are slightly twisted with the dihedral angle of 2.7(3) ${ }^{\circ}$. The Gly ligand takes an eclipsed conformation with the torsion angle of N3-C11-C12-O3 of 9.2(3) . The dihedral angle of the two pyridine rings of the bpa ligand is $28.5(1)^{\circ}$.

In the packing of $\mathbf{3}$, the $\pi-\pi$ interaction is not present. The hydrogen bonds are indicated by dashed lines in Fig. 7 . The complex molecules are connected by the H-bond networks therough the coordinated $\mathrm{Cl}$ atom, water molecule, and imino group of the bpa ligand and by the carboxylate and amino groups of the Gly ligand. The complex molecules are connected to each other by the available H-bonds.

The coordination bond distances indicate that the carboxylate $\mathrm{O}$ atom of the Gly ligand has a strong interaction with the $\mathrm{Cu}(\mathrm{II})$ atom with the bond $\mathrm{Cu}-\mathrm{O}$ distance values ranging from $1.949(5) \AA$ in 2 to $1.978(2) \AA$ in 3. The interaction between the $\mathrm{Cu}(\mathrm{II})$ atom and $\mathrm{N}$ atoms of the heterocylclic and Gly ligands resemble each other.

In all of the complexes, the heterocyclic compounds behave as $\mathrm{N}, \mathrm{N}$ bidentate ligands and the Gly ligand behaves as a $\mathrm{N}, \mathrm{O}$ bidentate ligand and $\mathrm{Cl}$ atom is also coordinated as the common ligand atom.

Complexes $\mathbf{1}$ and $\mathbf{3}$ have a similar distorted octahedral coordination geometry, while $\mathbf{2}$ has a distorted square pyramidal one. The order of the r.m.s. deviations of the $\mathrm{Cu}(\mathrm{II})$ atom is $\mathbf{2}>\mathbf{1}>\mathbf{3}$, while the order of the coordination bond lengths is the same. This is explained by the difference in the coordination geometries, in which the $\mathrm{Cu}$ (II) atoms in $\mathbf{1}$ and $\mathbf{3}$ are coordinated with two atoms in the axial positions, while in $\mathbf{2}$ it is coordinated only with the $\mathrm{Cl}$ atom in the axial position. The three H-bonds of the coordinated water molecule of $\mathbf{3}$, $\mathrm{O} 3-\mathrm{H} 14 \cdots \mathrm{Cl} 1, \mathrm{O} 3-\mathrm{H} 15 \cdots \mathrm{O} 2$, and $\mathrm{N} 3-\mathrm{H} 9 \cdots \mathrm{O} 3$ may draw the $\mathrm{Cu}$ atom toward the square plane, as reflected in the relatively small r.m.s. deviation. At present, we have not confirmed why complexes $\mathbf{1}$ and $\mathbf{3}$ take the distorted octahedral coordination geometry, and $\mathbf{2}$ the distorted square pyramidal one, in other words, why the difference in the coordination geometries appears at the apical sixth coordinate ligand atom. We can only say that the structures of the complexes

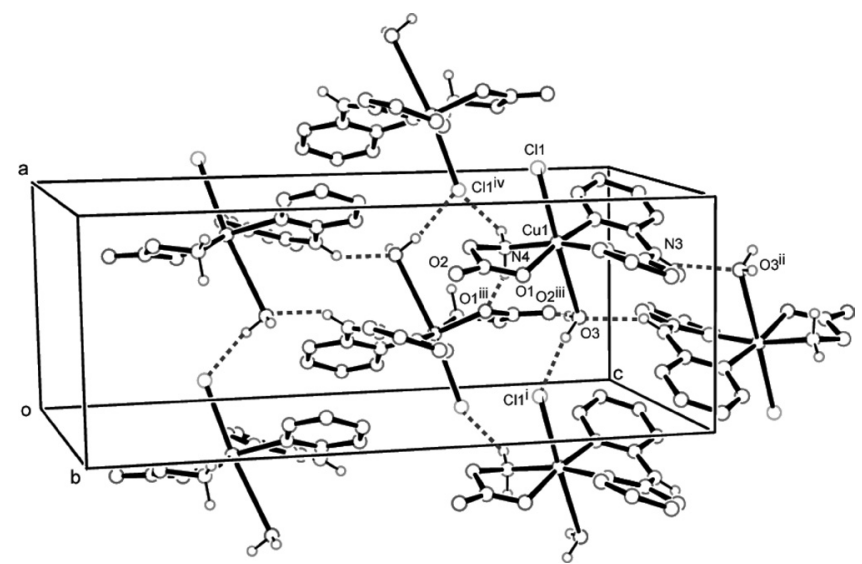

Fig. 7. View of the Packing Pattern in Complex 3 Including H-Bonds Indicated by Dashed Lines [Symmetry Codes: (i) $-x, 1 / 2+y, 1 / 2-z$; (ii) $-x,-y,-z]$ represent one of the energetically stable states in the crystal which includes various stabilizing factors such as hydrogen bonds, stacking interactions, steric hindrances, etc. affecting the structure of the coordination geometry.

DNA-Binding Studies Figure 8 shows the reduction in the fluorescence intensity of EB with the addition of the complexes to the EB-DNA solution. The extent of the fluorescence reduction of EB bound to DNA is used to determine the extent of binding of the complexes to DNA mainly by intercalation. $^{29,30)}$ The weak reduction in the fluorescence intensity caused by the addition of the complexes indicates a weak binding propensity of the complexes to DNA, which is indicated by the near slope in Fig. 8. The extent of the binding of complex $\mathbf{2}$ is predominant among the three complexes. From the reduction in the fluorescence intensity, the values of a linear Stern-Volmer quenching constant $\left(K_{\mathrm{sq}}\right)^{31)}$ which is the slope in Fig. 9 were calculated according to the Stern-Volmer equation, $I_{\mathrm{o}} / I=1+K_{\mathrm{sq}} r$, where $I_{\mathrm{o}}$ and $I$ represent the fluorescence intensities in the absence and presence of the complex, respectively, and $r$ is the concentration ratio of the complex to DNA. The values of the apparent binding constant $\left(K_{\text {app }}\right)^{32,33)}$ were also deduced from the slope of the quenching plot according to the equation $K_{\text {app,complex }}[\mathrm{Com}-$ plex $]=K_{\text {app,EB }}[\mathrm{EB}]$ where $K_{\text {app, EB }}$ is the apparent binding constant of EB assumed to be $10^{7} \mathrm{M}^{-1}$ and [Complex] is the concentration of the complex at $50 \%$ quenching. $K_{\mathrm{sq}}$ values were $3.2(1) \times 10^{-2}, 8.8(2) \times 10^{-2}$ and $4.2(1) \times 10^{-2}$, for $\mathbf{1}, \mathbf{2}$ and $\mathbf{3}$, respectively, and $K_{\text {app,complex }}$ values were $6.0(1) \times 10^{4} \mathrm{M}^{-1}$, $1.6(1) \times 10^{5} \mathrm{M}^{-1}$ and $8.0(2) \times 10^{4} \mathrm{M}^{-1}$ for 1,2 and 3 , respectively. These results indicate that both $K_{\mathrm{sq}}$ and $K_{\mathrm{app}}$ values of $\mathbf{2}$ are about two-fold greater than those of $\mathbf{1}$ and $\mathbf{3}$, although

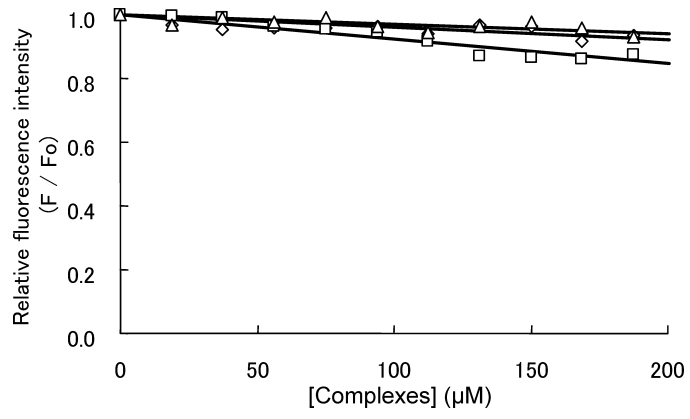

Fig. 8. Relative Fluorescence Intensity of the CT DNA-Bound Ethidium Bromide $(\mathrm{EB}, 10 \mu \mathrm{M})$ at Different Complex Concentrations in Tris- $\mathrm{HCl}$ $50 \mathrm{~mm}-\mathrm{NaCl} 50 \mathrm{~mm}$ Buffer, $\mathrm{pH} 7.4$ at $25^{\circ} \mathrm{C}$ with the Addition of Complex 1 $(\diamond)$, Complex $2(\square)$, and Complex $3(\triangle)$

The concentration of CT DNA was $100 \mu \mathrm{m}$. The excitation and emission wavelengths of EB were $545 \mathrm{~nm}$ and $600 \mathrm{~nm}$, respectively.

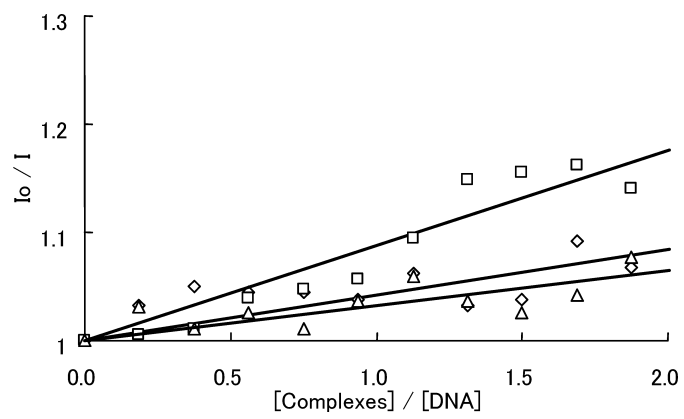

Fig. 9. Stern-Volmer Quenching Plots Using the Data in Fig. 8: Complex $1(\diamond)$, Complex $2(\square)$ and Complex $3(\triangle)$ 
$K_{\text {app }}$ values of 1, 2 and $\mathbf{3}$ are remarkably small as compared with that of EB. The DNA-binding propensity can be reflected in the relative order $\mathbf{2}>\mathbf{3} \geq \mathbf{1}$. The $\mathrm{Cu}$ (II) complexes with phen or bpy bind to DNA with several different binding modes, namely intercalation or nonintercalation, such as groove binding and binding to the phosphate group. ${ }^{9}{ }^{9}$ Chikira et $a l .{ }^{9)}$ investigated the orientation of $\left[\mathrm{Cu}\left(\text { phen) } X_{\mathrm{aa}}\right]^{n+}\right.$ (where $X_{\text {aa }}$ is an $\alpha$-amino acid) on DNA by recording electronparamagnetic resonance spectra of the complex. They suggested that a phen plane of $[\mathrm{Cu}(\text { phen }) \mathrm{Gly}]^{+}$intercalates between the base pairs of the double helical DNA, and Gly in the ternary complex is partly replaced with some coordinating atoms such as purine nitrogen and pyrimidine nitrogen of bases or phosphate oxygen atoms in DNA. They also suggested that the three fused aromatic rings of phen are critical for the intercalative binding of the complexes from the absence of the intercalated species for $[\mathrm{Cu}(\mathrm{bpy})]^{2+}$. Based on their results, the strongest binding of $\mathbf{2}$ among the three complexes may be explained by the intercalative binding of the phen plane of 2 between the nucleobases. The existence of the $\pi-\pi$ interaction between phen planes in the crystal packing of 2 (Figs. $5 \mathrm{a}, \mathrm{b})$ suggests the occurrence of intercalative binding. Chikira et al ${ }^{9)}$ suggested that the $\mathrm{Cl}^{-}$ion is not coordinated with $[\mathrm{Cu}(\text { phen })]^{2+}$ in solution. Therefore the coordinated $\mathrm{Cl}$ atom in the crystal structures of the three complexes may be replaced by the water oxygen atom as suggested, and as a result, positively charged complexes interact with the negatively charged DNA. The weak binding of complexes $\mathbf{1}$ and $\mathbf{3}$ may be explained by the nonintercalative binding modes, since they include the same or analogous ligands with $[\mathrm{Cu}(\mathrm{bpy})]^{2+}$, which does not intercalate into DNA. In this study, however, we did not investigate about the structures of the complexes in aqueous solution. At present we are not able to confirm whether the octahedral coordination geometry of $\mathbf{1}$ and $\mathbf{3}$ in the crystal structures or the dimeric units of $\mathbf{1}$ in the crystal structure (Fig. 3a) are maintained in aqueous solution, although the dimeric units of the $\mathrm{Cu}$ (II) ternary complex with bpy and $N$-propyl-norfloxacin in the crystal structure occurs as a mixture of dimeric and monomeric species in aqueous solution. ${ }^{34)}$ Therefore we can conclude safely that complexes 1, 2 and $\mathbf{3}$ interact with DNA, and but cannot suggest the exact binding mode of each complex. The precise explanation of the binding modes of the complexes will be confirmed in further studies.

DNA Cleavage The ability to cleave DNA of the complexes was investigated with gel electrophoresis using SC DNA. The electrophoretic migration patterns for the cleavage of SC DNA are usually characterized by three forms (forms I, II, III). ${ }^{2,3,32,33)}$ The fastest migration of the electrophoretic pattern is called form I, which reflects supercoiled DNA. A slower migration is form II, which reflects nicked circular DNA. Form III reflects linear open circular DNA, and migrates between form I and form II. Figure 10 shows the results of cleavage of SC DNA in the presence and absence of the same concentrations of the complexes in the presence of $\mathrm{H}_{2} \mathrm{O}_{2}$ and ascorbic acid. The results indicate that the production of form II is apparently enhanced by the presence of complexes $\mathbf{1}$ and 3 in the presence of $\mathrm{H}_{2} \mathrm{O}_{2}$ and ascorbic acid (lanes 5, 9), although form II is produced even in the presence of $\mathrm{H}_{2} \mathrm{O}_{2}$ and ascorbic acid alone (lane 3). With the same concentration of complex $\mathbf{2}$, form I was converted to form III or more cleaved to small fragments (lane 7). These phenomena suggest that complex $\mathbf{2}$ has the highest cleavage efficiency in the presence of $\mathrm{H}_{2} \mathrm{O}_{2}$ and ascorbic acid.

Figure 11 shows the electrophoretic migration patterns of SC DNA induced by increasing amounts of the complexes in the presence of $\mathrm{H}_{2} \mathrm{O}_{2}$ and ascorbic acid. Complexes $\mathbf{1}$ and $\mathbf{3}$ could convert form I to form II (lanes 5-9). In contrast, complex 2 could convert form I to form II (lanes 5, 6), form III (lane 7), and more small DNA fragments (lanes 8, 9). These results indicate that complex 2 induces intensive cleavage of SC DNA with the relative order $\mathbf{2}>\mathbf{3} \simeq \mathbf{1}$. The most effective DNA cleavage efficiency observed for complex $\mathbf{2}$ may be explained by the strongest binding ability of $\mathbf{2}$ with the intercalative binding mode. Chikira et al. ${ }^{9)}$ explained the intercalative binding mode of the ternary complex $[\mathrm{Cu}(\text { phen })(\mathrm{Gly})]^{+}$as follows: the apical position of the ter-

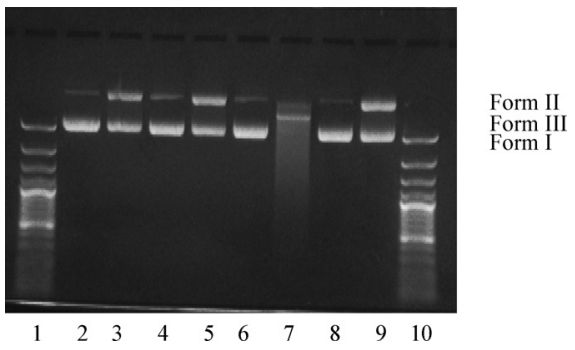

Fig. 10. Agarose Gel Electrophoresis of Oxidative Cleavage of SC DNA by the Complexes in the Presence and Absence of $\mathrm{H}_{2} \mathrm{O}_{2}$ and Ascorbic Acid in $10 \mathrm{~mm}$ Tris- $\mathrm{HCl}$ Buffer, $\mathrm{pH} 7.4$, Containing $50 \mathrm{~mm} \mathrm{NaCl}$ at $25^{\circ} \mathrm{C}$ for $1 \mathrm{~h}$

Lane: (1) and (10) Mark, (2) DNA alone, (3) DNA $+\mathrm{H}_{2} \mathrm{O}_{2}+$ ascorbic acid, (4) DNA+ complex 1, (5) DNA + complex $1+\mathrm{H}_{2} \mathrm{O}_{2}+$ ascorbic acid, (6) DNA + complex 2 , (7) DNA + complex 2+ $\mathrm{H}_{2} \mathrm{O}_{2}+$ ascorbic acid, (8) DNA + complex 3, (9) DNA+ complex $3+\mathrm{H}_{2} \mathrm{O}_{2}+$ ascorbic acid. For the oxidation cleavage reaction, $1 \mu \mathrm{g}$ of DNA was treated with $45 \mu \mathrm{M}$ of the complexes, $525 \mu \mathrm{M}$ of $\mathrm{H}_{2} \mathrm{O}_{2}$ and $525 \mu \mathrm{M}$ of ascorbic acid in $40 \mu \mathrm{l}$ of the reaction mixture.
(A)

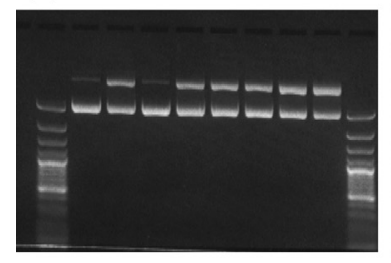

$\begin{array}{llllllllllll}1 & 2 & 3 & 4 & 5 & 6 & 7 & 8 & 9 & 10\end{array}$
(B)

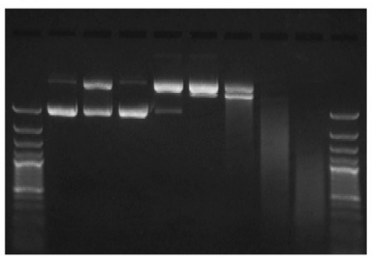

(C)

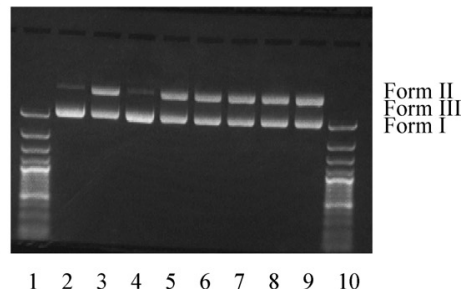

Fig. 11. Agarose Gel Electrophoresis of Oxidative Cleavage of SC DNA by Various Concentrations of the Complexes in the Presence and Absence of $\mathrm{H}_{2} \mathrm{O}_{2}$ and Ascorbic Acid in $10 \mathrm{~mm}$ Tris- $\mathrm{HCl}$ Buffer, $\mathrm{pH} 7.4$, Containing $50 \mathrm{~mm} \mathrm{NaCl}$ at $25^{\circ} \mathrm{C}$ for $1 \mathrm{~h}$

(A) Complex 1, (B) complex 2, (C) complex 3. Lane: (1) and (10) Mark, (2) DNA alone, (3) DNA $+\mathrm{H}_{2} \mathrm{O}_{2}+$ ascorbic acid, (4) DNA + complex (45 $\mu \mathrm{M}$ ), (5) DNA + complex $(15 \mu \mathrm{M})+\mathrm{H}_{2} \mathrm{O}_{2}+$ ascorbic acid, (6) DNA + complex $(30 \mu \mathrm{M})+\mathrm{H}_{2} \mathrm{O}_{2}+$ ascorbic acid. (7) DNA + complex $\left(45 \mu_{\mathrm{M}}\right)+\mathrm{H}_{2} \mathrm{O}_{2}+$ ascorbic acid, (8) DNA + complex $(60 \mu \mathrm{M})+\mathrm{H}_{2} \mathrm{O}_{2}+$ ascorbic acid, (9) DNA + complex $(75 \mu \mathrm{M})+\mathrm{H}_{2} \mathrm{O}_{2}+$ ascorbic acid. The concentrations of SC DNA, $\mathrm{H}_{2} \mathrm{O}_{2}$ and ascorbic acid were the same as in Fig. 10 . 


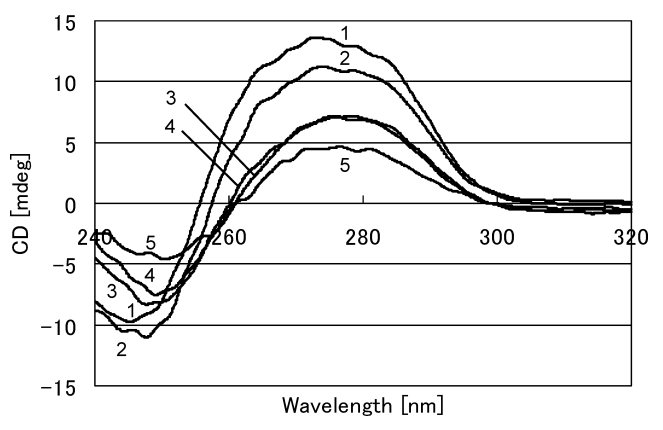

Fig. 12. CD Spectra of CT DNA in the Absence and Presence of the Complexes, $\mathrm{H}_{2} \mathrm{O}_{2}$, and Ascorbic Acid

1, DNA alone; 2, DNA $+\left(\mathrm{H}_{2} \mathrm{O}_{2}+\right.$ ascorbic acid $) ; 3$, DNA + complex $\mathbf{1}+\left(\mathrm{H}_{2} \mathrm{O}_{2}+\right.$ ascorbic acid); 4, DNA+complex $3+\left(\mathrm{H}_{2} \mathrm{O}_{2}+\right.$ ascorbic acid); 5, DNA+complex 2+ $\left(\mathrm{H}_{2} \mathrm{O}_{2}+\right.$ ascorbic acid). The CT DNA concentration was $150 \mu \mathrm{M}$, the concentration of each complex was $50 \mu \mathrm{m}$, and the concentrations of both $\mathrm{H}_{2} \mathrm{O}_{2}$ and ascorbic acid were $250 \mu \mathrm{M}$ in $10 \mathrm{~mm}$ Tris- $\mathrm{HCl}$ buffer, $\mathrm{pH} 7.4$, containing $50 \mathrm{~mm} \mathrm{NaCl}$ at $25^{\circ} \mathrm{C}$. The samples were preincubated for $1 \mathrm{~h}$ at $25^{\circ} \mathrm{C}$. CD spectra were measured at $25^{\circ} \mathrm{C}$.

nary complex coordinates to a base or a phosphate group, and the species with the phen plane oriented perpendicularly to a DNA double-helical axis is intercalated in the DNA. This binding mode will bring the complex molecules close to the phosphodiester backbone of DNA and accelerate the hydrolysis of the phosphodiester bonds by a nucleophilic attack or several oxidative cleavage pathways with free hydroxyl radicals or hydroxide ions formed due to the reaction of the $\mathrm{Cu}$ (II) complex with $\mathrm{H}_{2} \mathrm{O}_{2} \cdot{ }^{2,3,35-37)}$

The DNA cleavage efficiency of the complexes was also exmanined with CT DNA using the CD method. Figure 12 shows the CD spectra of CT DNA in the presence and absence of the complexes, $\mathrm{H}_{2} \mathrm{O}_{2}$, and ascorbic acid. CT DNA has characteristic $\mathrm{CD}$ bands consisting of a positive band near $275 \mathrm{~nm}$ due to base stacking and a negative band near $245 \mathrm{~nm}$ due to helicity characteristic of right-handed BDNA. ${ }^{2,38)}$ The intensities of both $\mathrm{CD}$ bands were decreased markedly in the presence of the complexes, $\mathrm{H}_{2} \mathrm{O}_{2}$, and ascorbic acid, especially in the case of complex $\mathbf{2}$, although a slight decrease occurred even in the presence of $\mathrm{H}_{2} \mathrm{O}_{2}$ and ascorbic acid alone. This result suggests that the decrease in the CD bands may be caused by the cleavage of CT DNA due to the complexes in the presence of $\mathrm{H}_{2} \mathrm{O}_{2}$ and ascorbic acid, as indicated by the electrophoretic migration patterns of SC DNA. The conformational degradation of CT DNA is caused by the complexes with the relative order $\mathbf{2}>\mathbf{3} \simeq \mathbf{1}$.

\section{Conclusion}

The coordination modes of three ternary $\mathrm{Cu}$ (II) complexes with different ligand atoms, N,O bidentate glycine ligand, and $\mathrm{N}, \mathrm{N}^{\prime}$ bidentate heterocyclic ligand have been structurally characterized. The interaction between the $\mathrm{Cu}$ (II) atom and ligand atoms are discussed including the packing effects.

The DNA binding and ability of the complexes to cleave DNA were studied. Each of the complexes showed a propensity to bind to CT DNA and cleave SC DNA in the presence of $\mathrm{H}_{2} \mathrm{O}_{2}$ and ascorbic acid. The complexes also degraded the conformation of CT DNA in the presence of $\mathrm{H}_{2} \mathrm{O}_{2}$ and ascorbic acid. Complex $2[\mathrm{Cu}(\mathrm{Gly})($ phen $) \mathrm{Cl}]$ showed the most effective DNA binding, cleavage, and conformational degradation as compared with the other two complexes 1 $[\mathrm{Cu}(\mathrm{Gly})(\mathrm{bpy}) \mathrm{Cl}]$ and $3\left[\mathrm{Cu}(\mathrm{Gly})(\mathrm{bpa})\left(\mathrm{H}_{2} \mathrm{O}\right) \mathrm{Cl}\right]$. The physicochemical properties of the three ternary $\mathrm{Cu}$ (II) complexes clarified in this study will be useful for further investigation of the biochemical behavior of $\mathrm{Cu}$ (II) complexes.

\section{References}

1) Yodoshi M., Odoko M., Okabe N., Acta Crystallogr., E61, m2299m2301 (2005).

2) Selvakumar B., Rajendiran V., Maheswari P. U., Stockli-Evans H., Palaniandavar M., J. Inorg. Biochem., 100, 316-330 (2006).

3) Li H., Le X.-Y., Pang D.-W., Deng H., Xu Z.-H., Lin Z.-H., J. Inorg Biochem., 99, 2240-2247 (2005).

4) Lu L.-P., Zhu M.-L., Yang P., Acta Crystallogr., C60, m21-m23 (2004).

5) Kasprzak K. S., Free Radic. Med., 32, 958 -967 (2002).

6) Santra B. K., Reddy P. A. N., Neelakanta G., Mahadevan S., Nethaji M., Chakravarty A. R., J. Inorg. Biochem., 89, 191-196 (2002).

7) Kelland L. R., Eur. J. Cancer, 41, 971-979 (2005).

8) Ranford J. D., Sadler P. J., Tocher D. A., J. Chem. Soc. Dalton Trans., 1993, 3393-3399 (1993).

9) Chikira M., Tomizawa Y., Fukita, D., Sugizaki T., Sugawara N., Yamazaki T., Sasano A., Shindo, H., Palaniandavar M., Antholine W. E., J. Inorg. Biochem., 89, 163-173 (2002).

10) Marshall L. E., Graham D. R., Reich K. A., Sigman D. S., Biochemistry, 20, 244-250 (1981).

11) Spassky A., Sigman D. S., Biochemistry, 24, 8050-8056 (1985)

12) Chen C. H. B., Milne L., Landgraf R., Perrin D. M., Sigman D. S., Chem. Biochem., 2, 735-740 (2001).

13) Thederahn T. B., Kuwabara M. D., Larsen T. A., Sigman D. S., J. Am. Chem. Soc., 111, 4941- 4946 (1989).

14) Antolini L., Marcotrigiano G., Menabue L., Pellacani G. C., Saladini M., Sola M., Inorg. Chem., 24, 3621-3626 (1985).

15) Antolini L., Marcotrigiano G., Menabue L., Pellacani G. C., Inorg. Chem., 22, 141-145 (1983).

16) Moreno-Esparza R., Molins E., Acta Crystallogr., C51, 1505-1508 (1995).

17) Venkatraman R., Zubkowski J. D., Valente E. J., Acta Crystallogr., C55, 1241-1243 (1999).

18) Solans X., Ruiz-Ramírez L., Martinez A., Gasque L., Briansó J. L., Acta Crystallogr., C44, 628-631 (1988).

19) Zheng Y.-Q., Kong Z.-P., Lin J.-L., Zhou L.-X., Z. Kristallogr., 216, 137-138 (2001)

20) Altomare A., Burla M., Camalli M., Cascarano G., Giacovazzo C., Guagliardi A., Moliterni A., Polidori G., Spagna P., J. Appl. Crystallogr., 32, 115-119 (1999).

21) Crystal Structure Analysis Package, Rigaku and Rigaku/MSC. The Woodlands, TX, U.S.A. (2000-2004).

22) Sheldrick G. M., SHELXL97. University of Göttingen, Germany, 1997.

23) Speck A. L., J. Appl. Crystallogr., 36, 7-13 (2003).

24) Waring M. J., J. Mol. Biol., 13, 269-282 (1965).

25) Le Pecq J. B., Paoletti C., J. Mol. Biol., 27, 87-106 (1967).

26) Mahadevan M. P., Inorg. Chem., 37, 3927-3934 (1998).

27) Thomas A. M., Naik A. D., Nethaji M., Chakravaty A. R., Inorg. Chim. Acta, 357, 2315-2323 (2004).

28) Reichman M. E., Rice S. A., Thomas C. A., Doty P., J. Am. Chem. Soc., 76, 3047-3053 (1954).

29) Baguley B. C., Bret M. L., Biochemistry, 23, 937-943 (1984).

30) Lakowicz J. R., Weber G., Biochemistry, 12, 4161-4170 (1973).

31) Ghosh S., Barve A. C., Kumbhar A. A., Kumbhar A. S., Puranik V. G., Datar P. A., Sonawane U. B., Joshi R. R., J. Inorg. Biochem., 100, $331-343$ (2006).

32) Dhar S., Nethaji M., Chakravarty A. R., J. Chem. Soc. Dalton Trans., 2004, 4180- 4184 (2004).

33) Lee M., Rhodes A. L., Wyatt M. D., Forrow S., Hartley J. A., Biochemistry, 32, 4237-4245 (1976).

34) Efthimiadou E. K., Thomadaki H., Sanakis Y., Raptopoulou C. P., Katsaros N., Scorilas A., Karaliota A., Psomas G., J. Inorg. Biochem., 101, 64-73 (2007).

35) Detmer C. A. III, Pamatong F. V., Bocarsly J. R., Inorg. Chem., 35, 6292-6298 (1996).

36) Meijler M. M., Zelenko O., Sigman D. S., J. Am. Chem. Soc., 119, 1135-1136 (1997).

37) Komiyama M., Takeda N., Shigekawa H., Chem. Commun., 1999, 1443-1451 (1999).

38) Collins J. G., Shields T. P., Barton J. K., J. Am. Chem. Soc., 116, 9840-9846 (1994). 